Artikel Penelitian

\title{
Kerupuk Pasir Ikan Kembung (Rastrelliger Kanagurta L.) sebagai Camilan Sehat Pencegah Hiperkolesterol
}

Crackers Sand Bloated Fish (Rastrelliger Kanagurta L.) as Healthy Snack to Prevent Hypercholesterolemia

Ibnu Malkan Bakhrul IImi ${ }^{*}$, Firlia Ayu Arini, Nur Intania Sofianita, Fira Firgicinia

Fakultas IImu-IImu Kesehatan, Jurusan IImu Gizi, Universitas Pembangunan Nasional "Veteran" Jakarta

*Korespondensi dengan penulis (ibnu.ilmi03@gmail.com)

Artikel ini dikirim pada tanggal 15 Desember 2016 dan dinyatakan diterima tanggal 8 Juni 2017. Artikel ini juga dipublikasi secara online melalui www.jatp.ift.or.id. Hak cipta dilindungi undang-undang. Dilarang diperbanyak untuk tujuan komersial.

Diproduksi oleh Indonesian Food Technologists® (C2017

\begin{abstract}
Abstrak
Penelitian ini bertujuan untuk membantu mencerdaskan dan mencegah kejadian hiperkolesterol pada masyarakat Indonesia mengingat prevalensi hiperkolesterol di Indonesia mencapai 35,9\%. Apabila kejadian ini tidak dicegah akan berisiko meningkatkan angka kejadian penyakit degeneratif seperti aterosklerosis, penyakit jantung coroner, diabetes mellitus, hepar dan penyakit ginjal. Omega 3 dikenal mampu mencegah hiperkolesterol. Penelitian ini bertujuan untuk melakukan penambahan tepung ikan kembung agar meningkatkan kandungan omega 3 pada kerupuk pasir. Formulasi yang diberikan yaitu substitusi tepung tapioka dan tepung ikan kembung dengan perbandingan F1 $(6,5: 50,5)$, F2 $(11,5: 45,5)$, dan F3 $(16,5: 50,5)$. Hasil penelitian menunjukkan bahwa formula terbaik hasil uji organoleptik adalah F2 yang mengandung 6,08\% air, abu 3,83\%, protein 21,69\%, lemak 0,36\%, karbohidrat 68,03\%, energi total 363,16 kkal, omega 3 (EPA dan DHA) sebesar 19,7 g dan 39,1 g per 100 gramnya. Kandungan EPA dan DHA pada kerupuk pasir per 100 gram dapat menjadi sumber EPA dan DHA dengan menyumbang $5,66 \%$ dan $11,25 \%$ kecukupan omega 3 pada anak.
\end{abstract}

Kata Kunci: kerupuk pasir, tepung ikan kembung, omega 3 (EPA dan DHA)

\section{Abstract}

This study aims to promote the brain activity and prevent the incidence of hypercholesterolemia in Indonesian society which was showed the prevalence of hypercholesterol reached 35.9\%. This incident may increase the risk of degenerative diseases such as atherosclerosis, coronary heart disease, diabetes mellitus, liver and kidney disease. Omega 3 was known to prevent hypercholesterolemia. This research was done to analyze the addition of flour fish in the sand chips processing in order to increase the content of omega 3 in the chips. The formulation was substitution of tapioca flour and flour fish meal with the ratio of $F 1(6,5: 50,5), F 2(11,5: 45,5)$, and F3 (16,5: 50,5). The best formula of organoleptic test result was F2 containing 6,08\% water, ash 3,83\%, protein 21,69\%, fat 0,36\%, carbohydrate 68,03\%, total energy 363,16 kcal, omega 3 (EPA And DHA) of $19.7 \mathrm{~g}$ and $39.1 \mathrm{~g}$ per $100 \mathrm{~g}$. EPA and DHA content in sand crackers per 100 gram could be used as source of EPA and DHA by contributing $5,66 \%$ and $11,25 \%$ sufficiency omega 3 in children.

Keywords: sand crackers, flour fish, omega 3 (EPA and DHA).

\section{Pendahuluan}

Penyakit kardiovaskular terbesar di Indonesia yaitu aterosklerosis, penyakit jantung coroner, diabetes mellitus, hepar dan penyakit ginjal. Beberapa penyakit tersebut disebabkan oleh tingginya kadar kolesterol darah yang melebihi batas normal atau disebut juga sebagai hiperkolesterolemia (Setiati, 2009). Berdasarkan laporan Badan Kesehatan Dunia (WHO) pada tahun 2002, tercatat sebanyak 4,4 juta kematian akibat hiperkolesterol atau sebesar 7,9\% dari jumlah total kematian di usia muda. Hal ini menunjukkan bahwa hiperkolesterol merupakan ancaman serius dalam kesehatan global. Data terbaru menunjukkan bahwa prevalensi hiperkolesterol untuk masyarakat usia diatas 15 tahun keatas sebesar 35,9\% dan sebagian besar berjenis kelamin laki-laki (30,0\%) dibandingkan dengan perempuan $(29,6 \%)$ (Riskesdas, 2013).

Asam lemak omega-3 merupakan salah satu asam lemak tidak jenuh yang dapat dirubah menjadi kolesterol di dalam tubuh, sehingga dapat dikatakan omega-3 menurunkan kadar kolesterol darah (Suptijah,
1999). Rekomendasi tentang asupan omega 3 untuk setiap orang yaitu 0,3-0,5 g/hari (EPA + DHA) dan 0,8$1,1 \mathrm{~g} /$ hari (asam linolenat) (WHO, 2008). Ikan Kembung (Rastrelliger kanagurta L.) merupakan ikan air laut yang banyak pada musim puncak (Maret-Juni). Pemanfaatan ikan kembung banyak digunakan oleh masyarakat luas karena ikan kembung banyak mengandung omega 3 dan omega 6 yang baik bagi pencegahan penyakit dan kecerdasan otak (Irmawan, 2009). Kandungan omega 3 pada berbagai jenis ikan per $100 \mathrm{~g}$ yaitu kembung $(8,5$ $\mathrm{g})$, sardine $(1,2 \mathrm{~g})$, tuna $(2,1 \mathrm{~g})$, cakalang $(1,5 \mathrm{~g})$, tenggiri $(2,6 \mathrm{~g})$, tongkol $(1,5 \mathrm{~g})$, dan teri $(1,4 \mathrm{~g})$ (Menristek, 2009).

Salah satu cara untuk meningkatkan konsumsi ikan kembung di Indonesia yaitu dengan mengolah ikan kembung menjadi pangan lokal yang umumnya dikonsumsi masyarakat setempat. Salah satu pangan lokal yang sering dikonsumsi yaitu kerupuk pasir. Kerupuk pasir biasanya dikonsumsi sebagai camilan atau pendamping makanan utama. Kerupuk dengan campuran tepung dan ikan mempunyai mutu yang lebih baik dari pada kerupuk tanpa campuran ikan. 
Berdasarkan permasalahan tersebut, peneliti tertarik untuk melakukan penelitian tentang pengembangan kerupuk pasir ikan kembung (Rastrelliger kanagurta L.) sebagai camilan sehat pencegah hiperkolesterolemia. Penambahan ikan kembung dalam bahan baku pembuatan kerupuk pasir agar meningkatkan cita rasa dan kandungan gizi terutama zat gizi omega-3 yang dapat mencegah tingginya kolesterol darah dan baik untuk kesehatan jantung. Oleh karena itu, penelitian ini bertujuan untuk melakukan penambahan tepung ikan kembung dalam proses pembuatan kerupuk pasir agar diperoleh angka omega-3 yang tinggi.

\section{Materi dan Metode \\ Materi}

Bahan yang digunakan dalam pembuatan kerupuk pasir ikan kembung didapatkan di Pasar Cileungsi, Bogor, Jawa Barat. Penelitian ini dilaksanakan selama 3 bulan mulai dari bulan Oktober 2016 sampai April 2017. Peralatan untuk membuat tepung ikan kembung yaitu loyang, blender besi dan ayakan mesh 80 . Peralatan untuk membuat kerupuk ikan kembung yaitu pasir, timbangan digital, gelas ukur, penghalus bumbu, baskom besar, mangkuk kecil, pisau, blender, talenan, kompor, dandang, tampah, wajan, sutil dan serok.

Penelitian meliputi proses pembuatan tepung ikan kembung dan formulasi kerupuk ikan kembung, uji organoleptik dan analisa kandungan gizi. Analisa kandungan gizi meliputi analisa kadar air, abu, protein, lemak (SNI 01-2891-1992) dan karbohidrat (Winarno, 1997), dan omega 3 (BBPP, 2013).

\section{Proses Pembuatan Tepung lkan}

Tepung ikan kembung didapatkan dengan mengukus dan mencincang daging ikan. Ikan yang sudah dikukus kemudian dioven dengan suhu $70-80^{\circ} \mathrm{C}$ selama 3-4 jam. Ikan yang sudah kering kemudian digiling lalu diayak hingga halus (80 mesh).

\section{Formulasi Kerupuk Pasir Ikan Kembung}

Formulasi kerupuk pasir ikan kembung didasarkan pada rekomendasi tentang asupan omega 3 untuk setiap orang yaitu $0,3-0,5 \mathrm{~g}$ per hari (EPA + DHA). Makanan camilan berupa kerupuk pasir dengan bahan baku ikan kembung diharapkan mampu memenuhi kecukupan omega 3 (EPA dan DHA) pada anak. Formula kerupuk pasir pada penelitian ini (Tabel 1) didasarkan pada perbedaan konsentrasi tepung ikan $(6,5 \%, 11,5 \%$, dan $16,5 \%)$. Penambahan tepung ikan sebanyak $11,5 \mathrm{~g}$ berpotensi menyumbangkan EPA sebesar $42 \%$ dan DHA sebesar $118,22 \%$.

\section{Analisis Statistik}

Uji organoleptik yang dilakukan meliputi uji hedonik dan uji mutu hedonik. Panelis semi terlatih yang digunakan sebanyak 50 orang. Produk kerupuk yang dinilai ada 3 formula. Parameter yang dinilai meliputi atribut warna, rasa, aroma, dan tekstur. Data hasil uji organoleptik dianalisa menggunakan uji
ANOVA, jika ada data yang berbeda nyata $(a<5)$ maka dilanjutkan dengan uji Duncan. Setelah didapatkan formula terpilih dilakukan pengujian kandungan gizi. Data kandungan gizi dianalisis menggunakan uji independent sample t-test. Pada uji kandungan gizi data dibandingkan dengan kerupuk udang komersial, melalui uji t.

\section{Hasil dan Pembahasan}

Kandungan Omega 3 (EPA dan DHA) Tepung Ikan Kembung

Analisis omega 3 (EPA dan DHA) dilakukan guna mengetahui seberapa besar kadar EPA dan DHA dalam tepung ikan kembung. Hasil analisis didapatkan bahwa kadar EPA dan DHA pada tepung ikan kembung segar masing-masing sebesar 19,7 g dan 39,1 g. Kandungan omega 3 yang terdiri dari EPA dan DHA pada masing- masing bagian tubuh ikan berbeda-beda. Pada penelitian ini bagian yang dipakai adalah bagian daging ikan. Kadar EPA dan DHA daging ikan kembung dari hasil penelitian Salamah et al. (2004) yaitu berada di antara 0,035-0,132 g per $100 \mathrm{~g}$ dan 0,041-0,716 g per $100 \mathrm{~g}$. Tingginya kadar EPA dan DHA pada kerupuk pasir ikan kembung dapat disebabkan oleh teknik pengolahan dan masa penyimpanan (Salamah, 2004).

\section{Kerupuk Pasir Ikan Kembung}

Tahapan dalam proses pembuatan kerupuk pasir ikan kembung meliputi pencampuran bahan-bahan, pengadonan, pencetakan, pengukusan, pendinginan, pengirisan dan pengeringan dengan sinar matahari. Mula-mula tepung ikan kembung (F1, F2, dan F3) dan tepung tapioka dicampur terlebih dahulu hingga merata, selanjutnya dilakukan pencampuran gula, garam, soda kue, merica, penyedap rasa dan bawang putih. Kemudian ditambahkan putih telur dan air sedikit demi sedikit. Lama pengadonan membutuhkan waktu sekitar 10-15 menit. Adonan yang sudah homogen dibentuk lonjong memanjang, berukuran kurang lebih panjang 10 $\mathrm{cm}$ dan diameter $5 \mathrm{~cm}$. Setelah itu adonan direbus pada suhu $100^{\circ} \mathrm{C}$ selama $20-30$ menit. Adonan yang sudah matang, didinginkan selama 8 jam dalam suhu ruang. Kemudian diiris tipis dan dikeringkan di bawah sinar matahari sampai kering.

Tabel 1. Formulasi Kerupuk Pasir Ikan Kembung

\begin{tabular}{|l|c|c|c|}
\hline \multirow{2}{*}{ Bahan (g) } & \multicolumn{3}{|c|}{ Berat Bahan (g) } \\
\cline { 2 - 4 } & $\mathrm{F} 1$ & $\mathrm{~F} 2$ & $\mathrm{~F} 3$ \\
\hline Tepung ikan & 6,5 & 11,5 & 16,5 \\
\hline Tepung Tapioka & 50,5 & 45,5 & 40,5 \\
\hline Soda Kue & 1 & 1 & 1 \\
\hline Gula & 1 & 1 & 1 \\
\hline Garam & 1 & 1 & 1 \\
\hline Putih telur & 11 & 11 & 11 \\
\hline Merica & 1 & 1 & 1 \\
\hline Bawang putih & 2 & 2 & 2 \\
\hline Penyedap rasa & 1 & 1 & 1 \\
\hline Air & 25 & 25 & 25 \\
\hline Jumlah & 100 & 100 & 100 \\
\hline Keterangan: & & & 100 \\
\hline
\end{tabular}

Keterangan: $\mathrm{F} 1=6,5 \%, \mathrm{~F} 2=11,5 \%, \mathrm{~F} 3=16,5 \%$ tepung ikan kembung dari berat total adonan. 
Karakteristik Organoleptik Kerupuk Pasir Ikan Kembung Hasil uji organoleptik kerupuk pasir ikan kembung dilakukan melalui uji mutu hedonik terdapat pada Figur 1 dan hasil uji kesukaan (hedonik), ditampilkan pada Figur 2. Penilaian organoleptik dilakukan dengan cara melihat, meraba, mencium dan mencicipi kerupuk pasir ikan kembung.

Secara keseluruhan formula yang diterima panelis adalah F2. Formula terpilih memiliki warna kuning, aroma agak amis, rasa agak gurih dan tekstur agak renyah. Formula terpilih kemudian dianalisis lebih lanjut yaitu analisis uji kandungan gizi kerupuk pasir ikan kembung.

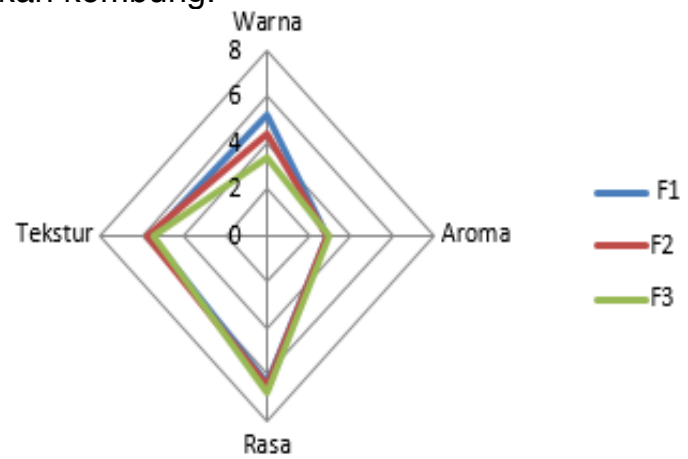

Figur 1. Hasil Mutu Hedonik Kerupuk Pasir Ikan Kembung.

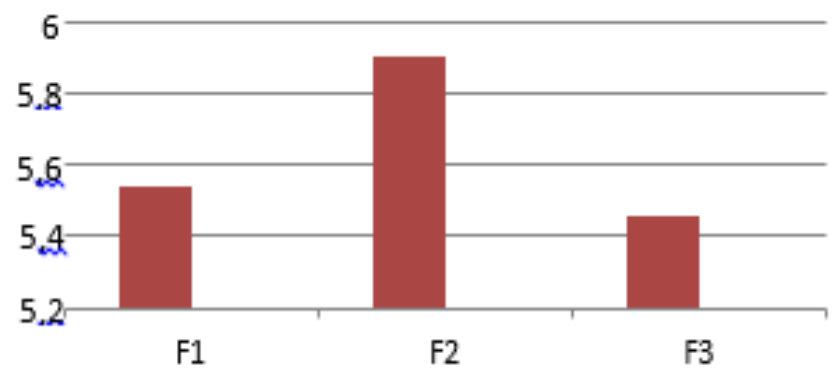

Figur 2. Hasil Hedonik Kerupuk Pasir Ikan Kembung.

Keterangan: sumbu $\mathrm{x}$ dan y masing-masing adalah macam formula dan skor kesukaan

Tabel 2. Kandungan Gizi Kerupuk Pasir Ikan Kembung F2 dan Kerupuk Udang Pasir Komersial

\begin{tabular}{lcccc}
\hline Zat Gizi & $\begin{array}{c}\text { Kerupuk } \\
\text { Pasir Ikan } \\
\text { Kembung }\end{array}$ & $\begin{array}{c}\text { Kerupuk } \\
\text { Udang } \\
\text { Pasir } \\
\text { Komersial }\end{array}$ & (p value) & SNI \\
\hline Air (\%) & 6,08 & 5,21 & 0,182 & $\begin{array}{c}\text { Max. } \\
\text { Abu (\%) }\end{array}$ \\
Krotein (\%) & 21,83 & 4,74 & 0,008 & Max. 3 \\
Lemak (\%) & 0,36 & 6,59 & 0,001 & Min. 5 \\
Karbohidrat & 68,03 & 62,76 & 0,238 & Max. 20 \\
(\%) & 19,7 & 4,0 & 0,004 & - \\
EPA (g) & 39,1 & 10,6 & 0,045 & - \\
DHA (g) & & & & \\
\hline
\end{tabular}

\section{Kandungan Zat Gizi Kerupuk Pasir Ikan Kembung}

Analisis yang telah dilakukan meliputi energi, kadar air, abu, protein, lemak, karbohidrat, EPA dan DHA (Tabel 2). Berdasarkan analisis kandungan gizi, dapat diketahui menurut SNI 01-2891-1992 kadar air, abu, dan lemak kerupuk pasir ikan kembung maupun kerupuk pasir komersial yang sudah memenuhi standar yang ditetapkan. Kadar air kerupuk pasir ikan kembung lebih tinggi dari kerupuk pasir komersial dan tidak terdapat perbedaan yang signifikan. Adanya peningkatan kadar air yang lebih terhadap kerupuk peningkatan pada kerupuk pasir ikan kembung diduga disebabkan karena kandungan pati yang terdapat pada kerupuk pasir ikan kembung.

Kadar abu kerupuk pasir ikan kembung lebih rendah dari kerupuk pasir komersial dan terdapat perbedaan yang signifikan. Hal ini mungkin terjadi karena bertambahnya kadar air pada kerupuk pasir udang. Menurut Winarno (1997) penurunan kadar air pada bahan pangan akan menyebabkan peningkatan konsentrasi kadar abu dan sebaliknya.

Kadar protein kerupuk pasir ikan kembung lebih tinggi dari kerupuk pasir komersial dan terdapat perbedaan yang signifikan. Tingginya kadar protein pada kerupuk pasir ikan kembung disebabkan karena kadar protein yang terkandung dalam bahan baku ikan kembung $(21,3 \%)$ yang relatif lebih tinggi dari udang $(11,4 \%)$ (PERSAGI, 2009) dan dimungkinkan penggunaan daging udang pada kerupuk udang pasir komersial lebih sedikit.

Kadar lemak kerupuk pasir ikan kembung lebih rendah dari kerupuk udang pasir komersial dan tidak terdapat perbedaan yang signifikan. Tingginya kadar lemak pada kerupuk pasir udang dimungkinkan karena perbedaan jumlah penambahan tepung tapioka antara kerupuk pasir ikan kembung dengan kerupuk pasir udang komersial.

Hasil perhitungan didapatkan kadar karbohidrat kerupuk pasir ikan kembung lebih rendah dari kerupuk udang pasir komersial dan terdapat perbedaan yang signifikan. Rendahnya kadar karbohidrat pada kerupuk pasir ikan kembung disebabkan oleh tingginya kadar air di dalam kerupuk tersebut sehingga mengurangi persentase karbohidrat di dalamnya.

Kadar EPA kerupuk pasir ikan kembung lebih tinggi dari kerupuk udang pasir komersial dan terdapat perbedaan yang signifikan. Tingginya kadar EPA pada kerupuk pasir ikan kembung dimungkinkan karena kandungan EPA dari ikan kembung. Kerupuk udang pasir komersial menggunakan bahan baku udang sehingga kandungan EPA pada produk tersebut lebih rendah. Hal ini menunjukkan penggunaan tepung ikan kembung sebanyak $11,5 \%$ dari total adonan sangat signifikan meningkatkan kadar EPA dibandingkan kerupuk udang pasir komersial. Kontribusi kerupuk pasir ikan kembung EPA dan DHA secara berturut-turut mencapai $5,66 \%$ dan $11,25 \%$, sedangkan kerupuk udang pasir komersial hanya memberi kontribusi sebesar $0,18 \%$ dan $3,04 \%$.

\section{Kesimpulan}

Bahan baku pembuatan kerupuk pasir ikan kembung ini terdiri dari tepung ikan kembung dan tepung tapioka. Formulasi yang diujikan dalam uji organoleptik sebanyak 3 formulasi. Berdasarkan uji organoleptik, formulasi terpilih yaitu F2 (11,5\% tepung ikan kembung) yang memili warna kuning, aroma agak amis, rasa agak gurih dan tekstur agak renyah. 
Berdasarkan uji kandungan gizi, formulasi terpilih dalam $100 \mathrm{~g}$ mengandung kadar air 6,08\%, abu 3,83\%, lemak $0,36 \%$, protein $21,69 \%$, karbohidrat $68,03 \%$, EPA $19,7 \%$ dan DHA 39,15\%. Kerupuk pasir ikan kembung mampu menyumbangkan EPA sebesar $5,66 \%$ dan DHA sebesar $11,25 \%$.

\section{Daftar Pustaka}

Standar Nasional Indonesia (SNI) 01-2713. 1999. Kerupuk Ikan. Dewan Standardisasi Nasional. Jakarta: Departemen Perindustrian.

Irmawan, S., 2009. Status Perikanan Ikan Kembung di Kabupaten Barru. Laporan Penelitian. Fakultas Perikanan dan IImu Kelautan, Universitas Brawijaya Malang.

Menristek, 2009. Pengolahan Ikan dan Daging. Kementrian Negara Riset dan Teknologi, Jakarta.

Persatuan Ahli Gizi Indonesia (PERSAGI). 2009. Tabel Komposisi Pangan Indonesia (TKPI). PT Gramedia, Jakarta.
Riset Kesehatan Dasar, 2013. Jakarta: Badan Penelitian dan Pengembangan Kesehatan, Kementerian Kesehatan RI.

Salamah, E., Hendarwan, dan Yunizal. 2004. Studi Tentang Asam Lemak Omega-3 Dari BagianBagian Tubuh Ikan Kembung Laki-Laki (Rastrelliger Kanagurta). Buletin Teknologi Hasil Perikanan Vol VIII No. II Tahun 2004.

Setiati, E. 2009. Bahaya Kolesterol, Mengenal, Mencegah dan Menanggulangi Kolesterol. Yogyakarta: Dokter Books, hlm. 31-32, 36.

Suptijah P. 1999. Studi Aktivitas Asam Lemak Omega-3 Ikan Laut pada Mencit sebagai Hewan Percobaan. Faperikan. IPB. Bogor.

Winarno, F.G. 1997. Kimia Pangan dan Gizi. PT Gramedia. Jakarta. 